\title{
The Impact of Policy Factors and Users' Awareness on Electricity-Saving Behaviors: From the Perspective of Habits and Investment
}

\author{
Lanlan Li ${ }^{1,2}$, Huayang Ming ${ }^{1}$, Ranran Yang 1,2,*(D) and Xuan Luo ${ }^{1,2}$ \\ 1 School of Management, Hefei University of Technology, Hefei 230009, China; 111428@hfut.edu.cn (L.L.); \\ minghuayangyu@163.com (H.M.); luxuan9989@126.com (X.L.) \\ 2 Key Laboratory of Process Optimization and Intelligent Decision-making, Hefei University of Technology, \\ Hefei 230009, China \\ * Correspondence: yangranran@hfut.edu.cn; Tel.: +86 18096684697
}

Received: 8 May 2020; Accepted: 9 June 2020; Published: 12 June 2020

\begin{abstract}
Exploring the factors affecting residents' electricity-saving behavior and their mechanisms of action is an important way to conserve regional energy and reduce emissions. Integrating the theory of planned behavior (TPB) and norm activation model (NAM) and introducing the external policy factors, a model of the factors influencing habituation and investment electricity-saving behavior was constructed and an empirical study of urban residents in Hefei city, China was conducted. The results show that residents' knowledge of the electricity price policy indirectly affects their habitual intentions by affecting their attitudes whereas residents' knowledge of the subsidy policy have direct effects on their investment intentions. Environmental concern can directly affect residents' habituation and investment intentions and also indirectly affect their habituation ones by affecting their personal moral norm. However, its indirect effect on the investment intention is not significant. Perceived behavioral control has a significant positive impact on residents' investment intentions and behaviors, but the impacts on their habituation ones are not significant. The relationships between the personal moral norm and the two kinds of intention and behavior are opposite to those of perceived behavior control. Relevant policy implications for the government, household appliance enterprises, and power enterprises are provided.
\end{abstract}

Keywords: household electricity-saving; habituation and investment behavior; TPB; NAM

\section{Introduction}

Burning fossil fuels produces large amounts of greenhouse gases. According to the "Global Energy and $\mathrm{CO}_{2}$ Status Report 2018" released by the International Energy Agency (IEA), energy-related $\mathrm{CO}_{2}$ emissions rose by $1.7 \%$ in 2018, and they reached the highest level in history of $33.1 \mathrm{Gt} \mathrm{CO}_{2}$. The power generation sector, which accounts for $38 \%$ of the total energy-related emissions, remains the highest emitter. The "Electricity Information Overview 2018" shows that in 2017, the electricity consumption of the global residential sector accounted for $27 \%$ of the total energy-related emissions. Energy saving and emission reduction in the residential sector have long been major concerns of the international community [1-3]. In recent years, with the rapid development of China's economy, the level of residents' income and urbanization have continued to increase, electrical energy replacement projects have been gradually promoted, and residential electricity consumption in China has maintained a high growth rate. As shown in Figure 1, this consumption grew from 145.195 billion kWh in 2000 to 1025 billion $\mathrm{kWh}$ in 2019 . This represents an average annual growth rate of $10.95 \%$, which is higher than the growth rate of total electricity consumption $(9.32 \%)$ and the growth rate of the industrial sector in the same period (8.77\%). In 2019, household electricity consumption accounted for $14 \%$ of 
the entire society's electricity consumption [4]. According to the forecast of Cao et al. [5], by 2025, the electricity consumption of Chinese residents will increase by $85-143 \%$ compared with 2009 , and the increase in residential electricity consumption will account for one-third of the increase in the total electricity consumption of the whole society. Therefore, tapping the energy saving and emission reduction potential of the residential sector is an important way to alleviate China's energy shortage and mitigate climate change.

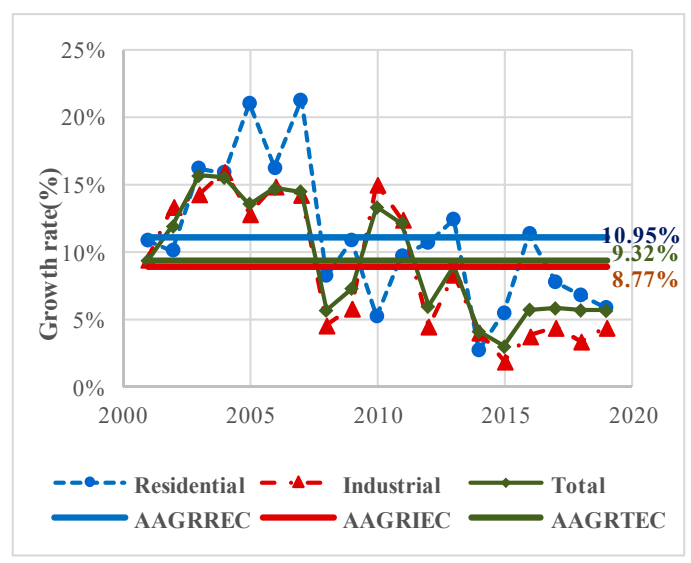

(a)

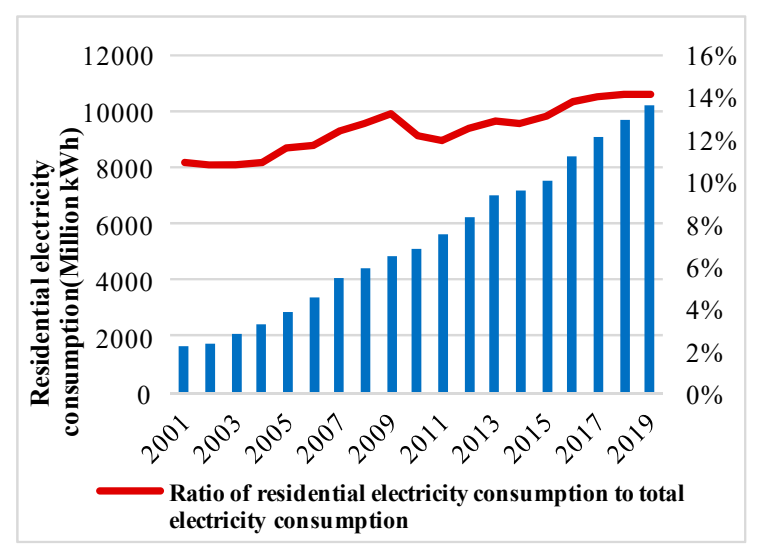

(b)

Figure 1. (a) Growth rate of China's electricity consumption in sectors from 2000 to 2019; (b) ratio of residential electricity consumption to total electricity consumption from 2001 to 2019. Data source: National Statistical Yearbook of China [4]. Note: AAGRREC: Average annual growth rate of residential electricity consumption; AAGRIEC: Average annual growth rate of industrial electricity consumption; AAGRTEC: Average annual growth rate of total electricity consumption.

The main factors that can influence household energy consumption are human behavior together with the household properties of the demographic characteristics, dwellings, household income, appliance ownership, and use, lifestyle, and climate [6-10]. Indeed, variations in residents' behaviors can cause significant differences in energy consumption between households with otherwise similar characteristics (e.g., dwelling types, income, and building energy performance) [11,12]. Determining the best way to promote positive changes in residents' electricity consumption behaviors has aroused wide concern among scholars. Generally speaking, residential energy-saving behavior can be divided into two types: Habituation behavior and investment behavior [13,14]. Habituation behavior, which is also known as curtailment behavior, refers to the direct reduction of household energy consumption by adjusting or changing certain behaviors [15], such as turning off lights when they are not needed, unplugging power outlets, and closing the refrigerator door promptly. Investment behavior, which is also known as efficiency behavior, refers to the indirect reduction of household energy consumption through investment in energy-saving equipment or technological transformation [16,17]. Examples of this behavior are the purchase of efficient air conditioning and installation of efficient heating systems [18]. Some studies have only been conducted on a certain type of energy-saving behavior $[15,19]$. Some scholars have also studied the differences between the motivation of two types of energy-saving behaviors from the perspective of the family attributes, and the results show that there are significant differences in the impact of income, age, gender, and other demographic factors, as well as housing factors, on the two types of energy-saving behavior [20,21]. However, the differences in the impact of psychological behavior factors, such as environmental concern and attitude towards electricity saving, on the two types of energy saving behaviors cannot be ignored $[17,22]$.

Theoretical models such as the theory of planned behavior (TPB) [23], theory of social cognition [24], and norm activation model (NAM) [25], are widely used to study the impact of psychological behavior factors on residential electricity-saving behavior $[23,26]$. Among them, the TPB is considered to be the most influential theory in explaining pro-environment intentions and behaviors [26], and it is widely 
used [2,27]. However, some scholars point out that the theory still has some limitations, because the theory only considers individual behavior as the result of an individual's rational plan; that is, it only considers rational egoism psychology and ignores the impact of altruistic psychology, such as moral norms and environmental awareness, on individual behavior [28,29]. Another popular behavior theory, the NAM, holds that human behavior is directly determined by its moral obligation or sense of responsibility for performing specific behaviors [30]; that is, individual altruistic psychology has an important impact on individual behavior decision-making. In this study, we establish a research framework of residential habituation and investment electricity-saving behavior that integrates the TPB and NAM models. Based on the real survey data of residential electricity consumption behavior, the structural equation model is used to explore the differences between the motivation of the two types of saving behaviors. The main contributions are reflected in two aspects. First, we construct an extended TPB-NAM model that includes two types of psychological factors: Egoistic and altruistic. We introduce the important altruistic psychological factor (environmental concern) into the model to explore its direct and indirect impact on the two types of electricity saving intentions. Second, we introduce the policy factor, which is an important external factor, and verify the direct and indirect impact of residents' knowledge of the electricity price policy and subsidy policy on their saving intentions. This will reveal the mechanism of the impact of policy factors.

The remainder of the study is arranged as follows. Section 2 reviews the theories of residential energy-saving behavior and proposes the research framework and research hypotheses. Section 3 introduces the research methods, and Section 4 presents the data analysis and results. In Section 5, we discuss the results and policy implications. The conclusions and limitations are given in Section 6.

\section{Theoretical and Conceptual Framework}

\subsection{Theoretical Model}

The TPB considers human behavior to be the result of a well-thought-out plan. It assumes that behavior is directly determined by behavioral intention. Meanwhile, the attitudes towards the behaviors, subjective norms, and perceived behavioral control are the intention antecedents. Icek [31] defines "attitudes" as positive or negative perceptions of performing a specific behavior. "Subjective norms" refer to the social pressure perceived by performing or not performing a certain behavior. "Perceived behavior control" refers to the perceived difficulty or capacity of conducting the behavior.

The NAM was proposed by Schwartz [32] to predict individual altruistic behavior. Personal norms are the core of NAM. The theory assumes that personal norms are the direct determinants of individuals' altruistic behavior. The awareness of consequences and ascription of responsibilities are two antecedents of personal norms. Schwartz [32] defines "personal norms" as a moral obligation to perform or fail to perform a particular behavior. The "awareness of consequences" refers to whether the individual is aware of the negative consequences of his or her altruistic behavior. "Ascription of responsibilities" refers to the individual's sense of responsibility for the negative consequences of his or her non-altruistic behavior.

TPB and NAM have been widely used in the study of pro-environment intention and behavior. Some related studies are shown in Table 1. In terms of introducing environmental concern and external policy factors, some models mentioned in Table 1 only consider the direct effects on the variables in the TPB and NAM, or only consider the moderating effect of external policies [17,25]. At the same, time these models do not consider the price of the electricity policy. Compared with the research model in Table 1, this model considers not only the direct effect of environmental concern and the two kinds of policy factors (the subsidy and the price of the electricity policy) on the variables in TPB and NAM, but also the indirect effects on electricity saving intentions. Based on this, the similarities and differences of their action paths and mechanisms on the two kinds of electricity-saving behaviors are further explored. However, this model does not focus on the effects of non-perceptual factors such as habits and emotions on residents' electricity saving behaviors. 
Table 1. Research based on the theory of planned behavior (TPB) and norm activation model (NAM).

\begin{tabular}{|c|c|c|c|}
\hline Authors & Objects and Samples & Research Questions & Model and Extension \\
\hline Ansu-Mensah and Bein [33] & Individual in Northern Cyprus & Energy conservation intentions & TPB, emotions and personal norms \\
\hline Ali et al. [34] & Households in Pakistan & $\begin{array}{l}\text { Purchasing energy-saving } \\
\text { household products }\end{array}$ & TPB, technology readiness Index \\
\hline Song et al. [25] & $\begin{array}{l}\text { Urban residents in Xuzhou city, } \\
\text { Jiangsu province of China }\end{array}$ & $\begin{array}{l}\text { Purchasing energy-saving } \\
\text { appliances }\end{array}$ & $\begin{array}{l}\text { NAM, environmental concern, perceived consumer } \\
\text { effectiveness, herd mentality and policy and propaganda }\end{array}$ \\
\hline Wang et al. [26] & $\begin{array}{l}\text { Residents in Hefei city, Anhui } \\
\text { province of China }\end{array}$ & $\begin{array}{l}\text { Household electricity saving } \\
\text { behavior }\end{array}$ & $\mathrm{TPB}$, personal moral norm, anticipated emotion, and habits \\
\hline Wang et al. [15] & Urban residents in China & $\begin{array}{l}\text { Habituation energy-saving } \\
\text { behaviors }\end{array}$ & TPB and NAM, policy environment \\
\hline Wang et al. [27] & $\begin{array}{c}\text { Employees in four Chinese cities: } \\
\text { Shanghai, Hefei, Nanjing and } \\
\text { Hangzhou }\end{array}$ & $\begin{array}{l}\text { Employee's electricity conservation } \\
\text { behavior in workplace }\end{array}$ & $\begin{array}{c}\text { NAM, anticipated emotion, habituation factor and personal } \\
\text { norm }\end{array}$ \\
\hline He and Zhan [35] & Residents in China & Adoption of electric vehicles & NAM, received consumer effectiveness and external costs \\
\hline Yang et al. [36] & $\begin{array}{l}\text { Residents in Beijing-Tianjin-Hebei } \\
\text { region of China. }\end{array}$ & $\begin{array}{l}\text { Purchasing green anti-smog } \\
\text { products }\end{array}$ & $\begin{array}{c}\text { NAM, smog knowledge, risk perception and information } \\
\text { seeking }\end{array}$ \\
\hline Kaffashi and Shamsudin [37] & Malaysian citizens & $\begin{array}{l}\text { Adoption of a low carbon } \\
\text { behaviors }\end{array}$ & $\begin{array}{l}\text { TPB, past behavior, moral obligations, modernity } \\
\text { acceptance, environmental concerns, and government's role }\end{array}$ \\
\hline Sujata et al. [38] & Malaysian citizens & Recycling behavior & $\mathrm{TPB}$, social media, self-efficacy, and governmental support \\
\hline
\end{tabular}




\subsection{Research Framework: Expansion and Integration of TPB and NAM}

As shown in Figure 2, this study establishes a research framework of habituation and investment electricity-saving behaviors that integrates the TPB and NAM models to explore the different impacts of egoistic psychological factors (attitude towards electricity saving, subjective norm, and perceived behavioral control) and altruistic psychological factors (environmental concern and personal moral norm) on the two types of residential saving behaviors. Two kinds of policy knowledge variables (knowledge of the electricity price policy and knowledge of the subsidy policy) are introduced as the pre-variables of the attitude towards electricity saving to verify the direct and indirect impacts of the knowledge of the electricity price policy on residents' habituation intentions and knowledge of the subsidy policy on residents' investment intentions. The environmental concern variable is introduced as the pre-variable of personal moral norm to explore its direct and indirect impact on the two types of intentions.

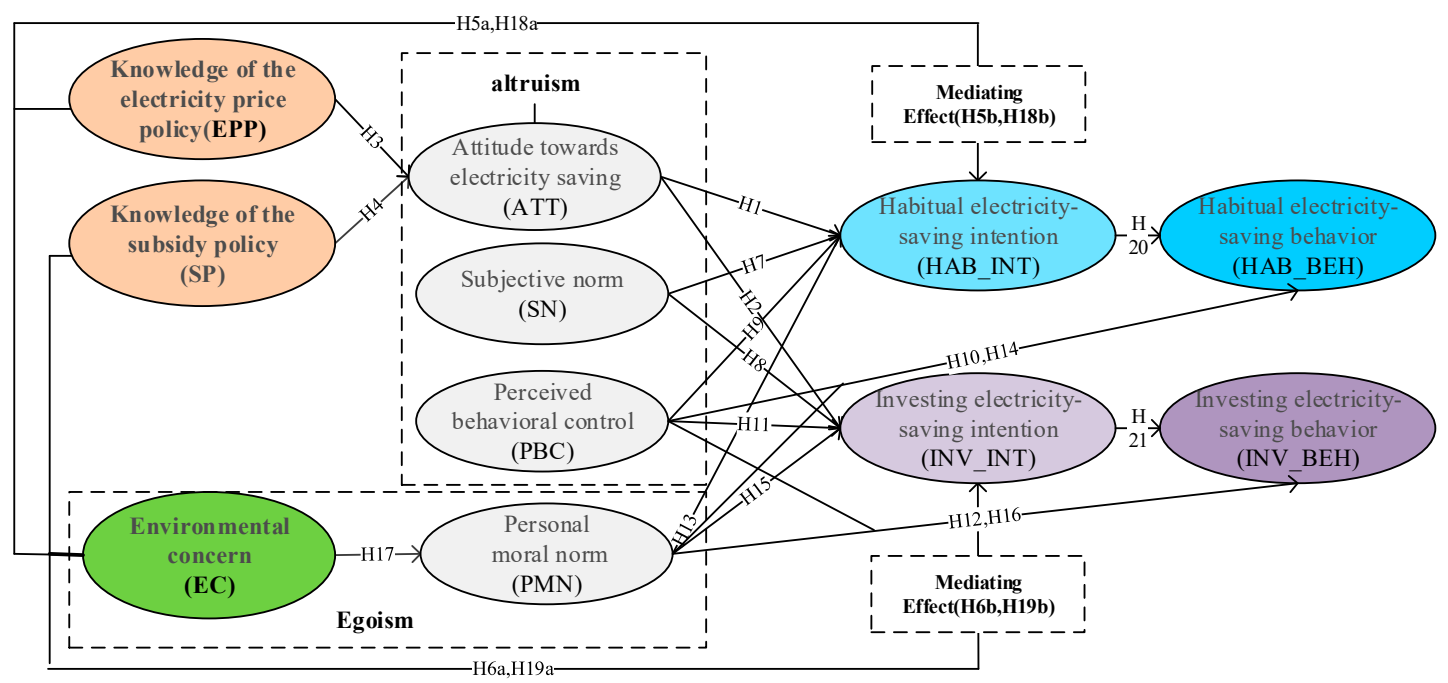

Figure 2. Extended TPN-NAM model: Research framework of habituation and investment electricity-saving behaviors.

\subsection{Theoretical Model}

\subsubsection{Relationship between ATT and Electricity-Saving Intention}

Attitude (ATT) refers to a positive or negative evaluation about certain specific behavior [39]. The more positive an individual's attitude is toward certain behavior, the stronger his intention to perform such behavior will be [40]. Many studies have confirmed that certain attitudes have a positive impact on pro-environment intentions and behaviors, such as the green product purchase behavior [41] and green travel behavior [42]. Studies by Zhang et al. [1] and Wang et al. [26] and other studies have shown that residents who have a positive attitude towards electricity saving are more willing to save electricity. Hence, we hypothesize that:

Hypothesis 1 (H1). Attitude has a significant positive impact on residents' habituation intentions.

Hypothesis 2 (H2). Attitude has a significant positive impact on residents' investment intentions.

\subsubsection{Relationship between Knowledge of Policy and Electricity-Saving Intention}

Government policy is an important external factor affecting personal environmental protection behavior, and its positive impact on residents' energy-saving behavior has been discussed in previous studies [43]. Zhang et al. [15] pointed out that the policy environment had an important positive impact on the daily energy-saving behavior of urban residents. Based on the empirical analysis 
of electric vehicle adoption among Chinese consumers, Yang et al. [44] confirmed that incentive and information policies show significant effects on consumers' electric vehicle adoption intentions. Meanwhile, considering the relevance and practicability of policies, scholars have tried to divide policy measures into different types and further explore the specific effects of each type. For example, Shi et al. [40] divided the policy measures related to the PM2.5 reduction behavior of Chinese consumers into three categories: Command and control policy, economic incentive policy, and education guidance policy. In addition, some scholars have focused on the moderating effect of policy factors on the relationship between psychological factors and energy-saving behavior [23,25], while few scholars have paid attention to the indirect effects of policy factors on energy-saving intentions. This study examines the impact of resident's knowledge of subsidy policy (SP) on the investment intentions and resident's knowledge of the electricity price policy (EPP) on the habituation intentions, and it pays attention to the indirect impact of policy factors with attitude as the mediator variable. We expect that the more understanding and knowledge residents have of relevant policies, the more positive their attitude towards electricity saving will be, which will thereby promote their intention to save electricity. Therefore, we make the following hypotheses with regard to the knowledge of the electricity price policy and the subsidy policy.

Hypothesis 3 (H3). Knowledge of the electricity price policy has a significant positive impact on residents' attitudes.

Hypothesis 4 (H4). Knowledge of the subsidy policy has a significant positive impact on residents' attitudes.

Hypothesis 5a (H5a). Knowledge of the electricity price policy has a significant positive impact on residents' habituation intentions.

Hypothesis 6a (H6a). Knowledge of the subsidy policy has a significant positive impact on residents' investment intentions.

Hypothesis $\mathbf{5 b} \mathbf{b} \mathbf{H} \mathbf{b} \mathbf{b})$. Attitude plays an intermediary role in the relationship between knowledge of the electricity price policy and residents' habituation intentions.

Hypothesis $\mathbf{6 b} \mathbf{( H 6 b )}$. Attitude plays an intermediary role in the relationship between knowledge of the subsidy policy and residents' investment intentions.

\subsubsection{Relationship between $\mathrm{SN}$ and Electricity-Saving Intention}

Subjective norm (SN) refers to perceptions of social pressures from important people (such as family, friends, and important others) to perform or not perform a particular behavior [30]. If individuals think that important people expect them to perform a certain behavior, they are more likely to perform that behavior [45]. A large number of studies on energy consumption behavior have shown that subjective norms have a positive impact on energy-saving intentions [46,47]. However, some studies have shown that subjective norms have a limited direct impact on individuals' energy-saving intentions [17,48]. Therefore, we hypothesize that:

Hypothesis 7 (H7). Subjective norm has a significant positive impact on residents' habituation intentions.

Hypothesis 8 (H8). Subjective norm has a significant positive impact on residents' investment intentions.

\subsubsection{Relationship between $P B C$ and Electricity-Saving Intention}

Perceived behavioral control (PBC) refers to the extent to which an individual perceives the performing of a particular behavior is easy or difficult [37]. When an individual believes that certain behavior is easy to perform or he is capable of performing the behavior, his intention to perform 
the behavior is higher [27]. In addition, an individual's judgment of how easy it is to perform a particular behavior has a direct impact on their behavior [49]. Many studies have verified the positive impact of perceived behavioral control on various intentions and behaviors, such as environmental behavior in a private-sphere context [50], recycling behavior [51], and fine particulate matter (PM2.5) reduction behavior [52]. For residential electricity-saving behavior, we expect that if residents believe that they have relevant knowledge and skills and are capable of saving at home, their intention to save electricity will be stronger, and the possibility of adopting saving behaviors will be higher. Therefore, we hypothesize that:

Hypothesis 9 (H9). Perceived behavioral control has a significant positive impact on residents' habituation intentions.

Hypothesis 10 (H10). Perceived behavioral control has a significant positive impact on residents' habituation behaviors.

Hypothesis 11 (H11). Perceived behavioral control has a significant positive impact on residents' investment intentions.

Hypothesis 12 (H12). Perceived behavioral control has a significant positive impact on residents' investment behaviors.

\subsubsection{Relationship between PMN and Electricity-Saving Intention}

Personal moral norm (PMN), also known as personal norm, refers to an individual's moral responsibility or moral obligation to perform certain actions [53] and is a core element of the norm activation model [54]. A higher personal moral norm can inspire individuals to produce pro-environment behaviors, and a lower personal moral norm can hinder the generation of such behavior [33]. In addition, many scholars have confirmed that there is a significant positive correlation between the personal norm and various pro-environment intentions [28]. For example, personal norm was found to be the most salient and influential factor in motivating citizens' environmental complaint intentions in the study of Zhang et al. [55]. For this study, we expect that individuals with higher personal moral norm will take more moral responsibilities in terms of residential electricity-saving behavior, and then it is possible to form saving intention and generate saving behavior. Hence, we hypothesize that:

Hypothesis 13 (H13). Personal moral norm has a significant positive impact on residents' habituation intentions.

Hypothesis 14 (H14). Personal moral norm has a significant positive impact on residents' habituation behaviors.

Hypothesis 15 (H15). Personal moral norm has a significant positive impact on residents' investment intentions.

Hypothesis 16 (H16). Personal moral norm has a significant positive impact on residents' investment behaviors.

\subsubsection{Relationship between EC and Electricity-Saving Intention}

Environmental concern (EC) refers to the degree of people's willingness to recognize and support the resolution of ecological problems. It is an important factor influencing people's decision-making on environmental protection [2]. Many studies have confirmed the positive relationship between environmental concern and individual environmental intention. Mishal et al. [56] and Kautish and Sharma [57] have found that environmental concern has a significant impact on consumers' environmental intentions, and Yadav and Pathak [39] found that environmental concern was the most significant predictor with regard to green purchase intention. In addition, environmental concern also has a positive impact on the personal moral norm [58]. In a study of efficient purchasing behavior of household appliances in China, Song et al. [25] found that environmental concern can activate the personal norm. For this study, we expect that, in addition to the direct impact, environmental concern also indirectly affects the resident's intention by activating the personal moral norm; that is, 
the personal moral norm plays a positive intermediary role in the relationship between environmental concern and the intention. In summary, we hypothesize that:

Hypothesis 17 (H17). Environmental concern has a significant positive impact on residents' personal moral norms.

Hypothesis 18a (H18a). Environmental concern has a significant positive impact on residents' habituation intentions.

Hypothesis 19a (H19a). Environmental concern has a significant positive impact on residents' investment intentions.

Hypothesis $\mathbf{1 8 b} \mathbf{~ ( H 1 8 b ) . ~ P e r s o n a l ~ m o r a l ~ n o r m ~ p l a y s ~ a n ~ i n t e r m e d i a r y ~ r o l e ~ i n ~ t h e ~ r e l a t i o n s h i p ~ b e t w e e n ~}$ environmental concern and residents' habituation intentions.

Hypothesis $19 b \mathbf{b}(\mathbf{H 1 9 b})$. Personal moral norm plays an intermediary role in the relationship between environmental concern and residents' investment intentions.

\subsubsection{Relationship between Electricity-Saving Intention and Behavior}

The actual behavior of an individual is often directly determined by his intention to act [26]. The greater the intention to perform a specific behavior, the higher the probability that the behavior will be performed [59,60]. Similarly, in terms of residential energy-saving behavior, residents' energy-saving intentions also have an important positive impact on their behaviors [46,61]. According to a study by Ding et al. [62], residents' intentions have a significant positive impact on both their buying choices and daily use behaviors. Residential intention is an important part of their behavior. Therefore, we hypothesize that:

Hypothesis 20 (H20). Residents' habituation electricity-saving intentions have significant positive impacts on their habituation behaviors.

Hypothesis 21 (H21). Residents' investment electricity-saving intentions have significant positive impacts on their investment behaviors.

\section{Materials and Methods}

\subsection{Questionnaire Design}

The questionnaire consisted of two parts. The first part involved the collection of demographic information of the respondents (age, educational level, annual income, and health level). The second part consisted of constructing the two types of residential electricity-saving behaviors and their influencing factors, which covered the 11 variables mentioned in the research framework and hypotheses. The constructs involved in this study are latent variables, and they are measured with multiple item scales. All the items were developed from prior related research. Meanwhile, in order to be consistent with the background of this study, we made corresponding modifications to the wording of individual items. The items were measured on a five-point Likert scale ranging from 1 ("strongly disagree") to 5 ("strongly agree"). In order to verify the rationality and applicability of the items in the scale, we first performed a preliminary survey in Hefei. According to the pre-survey feedback, we modified and improved some items accordingly. The final constructs, items, and specific literature sources are shown in Table 2. 
Table 2. Constructs and measurement items.

\begin{tabular}{|c|c|c|}
\hline Constructs & Measurement Items & Source \\
\hline $\begin{array}{c}\text { Attitude towards } \\
\text { electricity saving (ATT) }\end{array}$ & $\begin{array}{l}\text { Saving electricity is a good idea. } \\
\text { Saving electricity is beneficial. } \\
\text { Saving electricity is pleasant. }\end{array}$ & [48] \\
\hline Subjective norm (SN) & $\begin{array}{l}\text { My family encourage me to save electricity. } \\
\text { My friends around me encourage me to save electricity. } \\
\text { The publicity of energy conservation and pro-environment by the government and environmental protection departments will affect my } \\
\text { electricity consumption behavior. }\end{array}$ & {$[15,48]$} \\
\hline $\begin{array}{l}\text { Perceived behavioral } \\
\text { control (PBC) }\end{array}$ & $\begin{array}{l}\text { I am capable of saving electricity in my home. } \\
\text { I have knowledge and skills to save electricity in my home. } \\
\text { It's easy for me to save electricity in my home if I want to. }\end{array}$ & [26] \\
\hline $\begin{array}{l}\text { Personal moral norm } \\
\text { (PMN) }\end{array}$ & $\begin{array}{l}\text { I have a commitment to save electricity in order to contribute to environmental improvement. } \\
\text { Wasting electricity in my home are against my principles of environmental protection. } \\
\text { I would feel guilty about not saving electricity in my home. }\end{array}$ & [30] \\
\hline $\begin{array}{l}\text { Knowledge of the } \\
\text { electricity price policy } \\
\text { (EPP) }\end{array}$ & $\begin{array}{l}\text { I am very concerned about electricity price policy. } \\
\text { I know well about the structure of the current block tariffs policy, such as the price and threshold of electricity of each block. } \\
\text { I know well about the significance of the block tariffs policy, such as helping to save electricity and ease cross-subsidy. }\end{array}$ & [63] \\
\hline $\begin{array}{l}\text { Knowledge of the } \\
\text { subsidy policy (SP) }\end{array}$ & $\begin{array}{l}\text { I am concerned about the government subsidy policy for purchasing efficient appliances. } \\
\text { I know well about the current subsidy policies for the purchase of efficient appliances, such as the type of goods and subsidy standards. } \\
\text { I think the government in my area subsidizes the purchase of energy- saving appliances very heavily }\end{array}$ & [64] \\
\hline $\begin{array}{l}\text { Environmental concern } \\
\text { (EC) }\end{array}$ & $\begin{array}{l}\text { I am extremely worried about the state of China's energy consumption and environmental pollution. } \\
\text { I am very concerned that the current environmental problems will affect human health. } \\
\text { Reducing electricity consumption is necessary for environmental reasons. } \\
\text { Excessive energy consumption will bring many environmental problems such as haze pollution. }\end{array}$ & [52] \\
\hline $\begin{array}{c}\text { Habituation } \\
\text { electricity-saving } \\
\text { intention (HAB_INT) }\end{array}$ & $\begin{array}{l}\text { I intend to turn off the light in an empty room. } \\
\text { I intend to close the door of the refrigerator in time. } \\
\text { When the weather is not very hot or cold, I intend to reduce the time of using air conditioning or heating equipment. }\end{array}$ & {$[1565]$} \\
\hline $\begin{array}{l}\text { Habituation } \\
\text { electricity-saving } \\
\text { behavior (HAB_BEH) }\end{array}$ & $\begin{array}{l}\text { I always turn off the light in time. } \\
\text { When the room is empty, I always turn off the TV, air conditioner and so on. } \\
\text { I always set the air conditioner at the right temperature, not the lowest or highest. }\end{array}$ & \\
\hline $\begin{array}{l}\text { Investing } \\
\text { electricity-saving } \\
\text { intention (INV_INT) }\end{array}$ & $\begin{array}{l}\text { I prefer to buy efficient appliances rather than ordinary ones. } \\
\text { I am willing to pay a slightly higher price for efficient appliance. } \\
\text { When my home is decorated, I am willing to use thermal insulation material to achieve energy conservation and insulation. }\end{array}$ & \\
\hline $\begin{array}{l}\text { Investing } \\
\text { electricity-saving } \\
\text { behavior (INV_BEH) }\end{array}$ & $\begin{array}{l}\text { I have bought some efficient appliances to save electricity. } \\
\text { All the lamps in my house are energy-saving. } \\
\text { I have an efficient air conditioner at home. }\end{array}$ & \\
\hline
\end{tabular}




\subsection{Samples Distribution}

Residents in Hefei were selected as the survey objects for this study, and a third-party questionnaire company, SoJump, was commissioned to carry out the survey. Hefei, the capital city of Anhui province, is located in the central-eastern part of China, and a sub-center of the Yangtze River Delta urban agglomeration. It is a representative region of China's economic development. Meanwhile, it is also a strategic two-node city of the Belt and Road Initiative and the Yangtze River Economic Belt. It is a microcosm of China's economic development and residential energy consumption trend. As shown in Figure 3, Hefei has witnessed a rapid economic growth with an average annual GDP growth rate of $17.36 \%$ between 2009 and 2018. The economic growth is accompanied by the rapid increase of electricity consumption. In 2009, the total amount of electricity consumption in Hefei was $105.93 \mathrm{TWh}$, while in 2018, it became 344.83 TWh, with an average $14.16 \%$ annual growth. In 2018, the residential electricity consumption in Hefei was $63.16 \mathrm{TWh}$, an annual increase of $15.31 \%$. Among them, the electricity consumption of the urban residents was $46.06 \mathrm{TWh}$, an annual increase of $17 \%[67,68]$. In the past five years, the ratio of residential electricity consumption in the total electricity consumption was close to $20 \%$ in Hefei. Therefore, Hefei can be a typical case for the study of residential electricity-saving behavior.

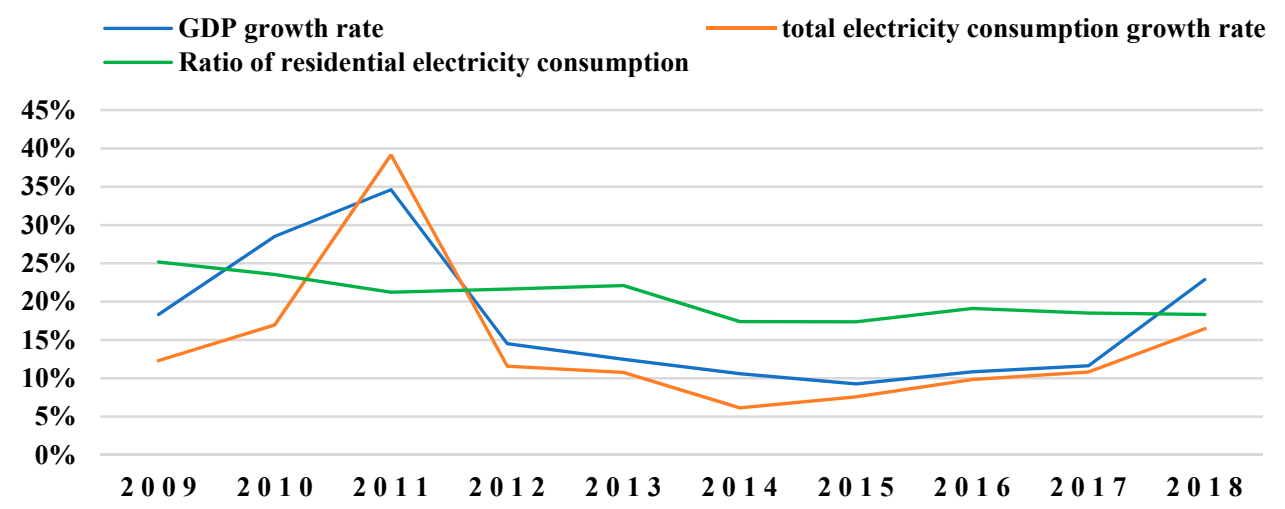

Figure 3. Annual growth rate of GDP and electricity consumption in Hefei in 2009 2018. Data source: Hefei statistical yearbook [68]

SoJump's sample database contains 2.6 million members with a diverse sample composition. It guarantees the quality of the samples through four steps: 1) Sending questionnaires to the qualified population; 2) controlling the filling-in process; 3) screening systematically; and 4) conducting manual screening. SoJump distributed 1200 questionnaires to members of its database in Hefei in October 2019 and received 607 responses with a response rate of 50.6\%. Through system detection and manual screening, invalid questionnaires with logic errors were deleted; the questionnaires that were completed in less than 2 minutes were deleted, since these respondents may not have read the questionnaires carefully, so the answers were not credible; also the questionnaires that took more than 10 minutes to answer were deleted, since answers offered after long thinking may bear personal bias or emotions, rather than an immediate response, so the data quality of these questionnaires was difficult to evaluate. We ended up with 480 valid samples. The effective sample rate was $79.1 \%$. The sample size fulfills the requirement for a large sample in statistics. Also, in many existing relevant literatures, the questionnaire survey was conducted by the SoJump company, and the sample size is similar to ours, such as 396 samples in He and Zhan [35], 419 samples in Ru et al. [42], 450 samples in Ru et al. [47], and so on.

Table 3 lists the demographic information of the respondents. As shown in Table 3, more than $80 \%(84.17 \%)$ of the respondents were between 18 and 40 years old. More than $60 \%$ of the respondents had a bachelor's degree or above. More than half (55.83\%) of the respondents had an annual income of between 100,000 and 300,000 RMB, while $28.1 \%$ had an annual income of less than 100,000 RMB. Finally, more than $60 \%$ of people thought they are healthy or very healthy. 
Table 3. Demographic information of respondents. $(\mathrm{N}=480)$.

\begin{tabular}{|c|c|c|c|c|c|}
\hline Demographics & \multicolumn{2}{|c|}{ Frequencies (Percentages) } & Demographics & \multicolumn{2}{|c|}{ Frequencies (Percentages) } \\
\hline \multirow{4}{*}{ Age } & Under 18 & $6(1.25 \%)$ & \multirow{4}{*}{$\begin{array}{l}\text { Annual income } \\
\text { (RMB) }\end{array}$} & Less than & $138(28.75 \%)$ \\
\hline & $18-40$ & $404(84.17 \%)$ & & $100,000-300,000$ & $268(55.83 \%)$ \\
\hline & $41-65$ & $70(14.58 \%)$ & & $\begin{array}{l}\text { More than } \\
300,000\end{array}$ & $74(15.42 \%)$ \\
\hline & Over 65 & 0 & & & \\
\hline \multirow{5}{*}{$\begin{array}{l}\text { Educational } \\
\text { level }\end{array}$} & Junior high school or below & $17(3.54 \%)$ & \multirow{5}{*}{ Health level } & Very unhealthy & $2(0.42 \%)$ \\
\hline & High school or technical & $46(9.58 \%)$ & & unhealthy & $23(4.79 \%)$ \\
\hline & Associate degree & $108(22.50 \%)$ & & General & $126(26.25 \%)$ \\
\hline & Bachelor's degree & $243(50.63 \%)$ & & healthy & $238(49.58 \%)$ \\
\hline & Master's degree and phD & $66(13.75 \%)$ & & Very healthy & $91(18.96 \%)$ \\
\hline
\end{tabular}

\subsection{Data Analysis Method}

The structural equation modeling (SEM) technique was used for data analysis in this study and followed the two-step approach for assessing the measurement model and structural model [69]. The SEM technique is a commonly used method to test the relationship between multi-item constructs [70]. The test is mainly based on two statistical methods: The covariance-based SEM and variance-based partial least squares (PLS) methods. In general, covariance-based SEM is suitable for theoretical verification or comparative research, while PLS can be applied to structural equation models with a large number of structures and complex relationships. Furthermore, the PLS method is suitable for establishing a multi-relation test theory that does not need normally distributed data [71,72]. Considering the above characteristics and advantages of PLS, this study used PLS to do an empirical study. With the statistical software SmartPLS 3.2.7, we first tested the measurement model to evaluate the reliability and validity of all constructs and then tested the structural model to test the hypotheses.

\section{Results}

\subsection{Construct Validity}

Construct validity refers to the confidence level that the sample measurements can represent the overall true score [2]. Smart PLS 3.2.7 was used to measure the factor loading and cross loading of each construct, and the results show that the factor loading of all constructs was greater than the cross loading. In addition, as shown in Table 4, the normalized factor loading for all constructs was greater than the recommended benchmark of 0.5. This indicates that the scale used in the study has a high construct validity.

Table 4. Results of confirmatory factor analysis.

\begin{tabular}{|c|c|c|c|c|c|}
\hline Construct & Item & $\begin{array}{c}\text { Standardized } \\
\text { Factor Loading }\end{array}$ & $\begin{array}{l}\text { Cronbach's } \\
\text { Alpha }\end{array}$ & $\begin{array}{l}\text { Composite } \\
\text { Reliability }\end{array}$ & AVE \\
\hline \multirow{4}{*}{$\begin{array}{l}\text { Attitude towards electricity } \\
\text { saving (ATT) }\end{array}$} & ATT1 & $0.889^{* * *}$ & \multirow{4}{*}{0.866} & \multirow{4}{*}{0.918} & \multirow{4}{*}{0.788} \\
\hline & ATT2 & $0.893^{* * *}$ & & & \\
\hline & ATT3 & $0.882^{* * *}$ & & & \\
\hline & SN1 & $0.795^{* * *}$ & & & \\
\hline \multirow[t]{2}{*}{ Subjective norm (SN) } & SN2 & $0.824^{* * *}$ & \multirow{2}{*}{0.744} & \multirow[t]{2}{*}{0.854} & \multirow{2}{*}{0.661} \\
\hline & SN3 & $0.82^{* * *}$ & & & \\
\hline \multirow{4}{*}{$\begin{array}{l}\text { Perceived behavioral control } \\
\text { (PBC) }\end{array}$} & PBC1 & $0.842^{* * *}$ & \multirow{4}{*}{0.796} & \multirow{4}{*}{0.880} & \multirow{4}{*}{0.709} \\
\hline & $\mathrm{PBC} 2$ & $0.841^{* * *}$ & & & \\
\hline & РBC3 & $0.843^{* * *}$ & & & \\
\hline & PMN1 & $0.847^{* * *}$ & & & \\
\hline \multirow[t]{2}{*}{ Personal moral norm (PMN) } & PMN2 & $0.861^{* * *}$ & \multirow[t]{2}{*}{0.770} & \multirow[t]{2}{*}{0.868} & \multirow[t]{2}{*}{0.686} \\
\hline & PMN3 & $0.774^{* * *}$ & & & \\
\hline
\end{tabular}


Table 4. Cont.

\begin{tabular}{|c|c|c|c|c|c|}
\hline Construct & Item & $\begin{array}{c}\text { Standardized } \\
\text { Factor Loading }\end{array}$ & $\begin{array}{c}\text { Cronbach's } \\
\text { Alpha }\end{array}$ & $\begin{array}{l}\text { Composite } \\
\text { Reliability }\end{array}$ & AVE \\
\hline \multirow{3}{*}{$\begin{array}{l}\text { Knowledge of the electricity } \\
\text { price policy (EPP) }\end{array}$} & EPP1 & $0.786^{* * *}$ & \multirow{3}{*}{0.813} & \multirow{3}{*}{0.885} & \multirow{3}{*}{0.721} \\
\hline & EPP2 & $0.876^{* * *}$ & & & \\
\hline & EPP3 & $0.882 * * *$ & & & \\
\hline \multirow{3}{*}{$\begin{array}{l}\text { Knowledge of the subsidy } \\
\text { policy (SP) }\end{array}$} & SP1 & $0.927^{* * *}$ & \multirow{3}{*}{0.894} & \multirow{3}{*}{0.934} & \multirow{3}{*}{0.825} \\
\hline & SP2 & $0.938^{* * *}$ & & & \\
\hline & SP3 & $0.858^{* * *}$ & & & \\
\hline \multirow{4}{*}{ Environmental concern (EC) } & EC1 & $0.85^{* * *}$ & \multirow{4}{*}{0.885} & \multirow{4}{*}{0.921} & \multirow{4}{*}{0.744} \\
\hline & $\mathrm{EC} 2$ & $0.852 * * *$ & & & \\
\hline & EC3 & $0.89 * * *$ & & & \\
\hline & EC4 & $0.857^{* * *}$ & & & \\
\hline Investment & INV_INT1 & $0.851 * * *$ & \multirow{3}{*}{0.799} & \multirow{3}{*}{0.881} & \multirow{3}{*}{0.713} \\
\hline \multirow{2}{*}{$\begin{array}{l}\text { electricity-saving intention } \\
\text { (INV_INT) }\end{array}$} & INV_INT2 & $0.811^{* * *}$ & & & \\
\hline & INV_INT3 & $0.87^{* * *}$ & & & \\
\hline Investment & INV_BEH1 & $0.871^{* * *}$ & \multirow{3}{*}{0.828} & \multirow{3}{*}{0.897} & \multirow{3}{*}{0.743} \\
\hline \multirow{2}{*}{$\begin{array}{l}\text { electricity-saving behavior } \\
\text { (INV_BEH) }\end{array}$} & INV_BEH2 & $0.865^{* * *}$ & & & \\
\hline & INV_BEH3 & $0.849^{* * *}$ & & & \\
\hline \multirow{3}{*}{$\begin{array}{c}\text { Habituation electricity- } \\
\text { saving intention (HAB_INT) }\end{array}$} & HAB_INT1 & $0.917^{* * *}$ & \multirow{3}{*}{0.877} & \multirow{3}{*}{0.924} & \multirow{3}{*}{0.802} \\
\hline & HAB_INT2 & $0.891 * * *$ & & & \\
\hline & HAB_INT3 & $0.879^{* * *}$ & & & \\
\hline \multirow{3}{*}{$\begin{array}{c}\text { Habituation } \\
\text { electricity-saving behavior } \\
\text { (HAB BEH) }\end{array}$} & HAB_BEH1 & $0.872^{* * *}$ & \multirow{3}{*}{0.843} & \multirow{3}{*}{0.905} & \multirow{3}{*}{0.761} \\
\hline & HAB_BEH2 & $0.89 * * *$ & & & \\
\hline & HAB_BEH3 & $0.854^{* * *}$ & & & \\
\hline
\end{tabular}

\subsection{Convergence Validity}

Convergence validity refers to the degree of consistency of multiple items reflecting the same variable [2]. The standardized factor loading coefficient and average extraction variation (AVE) were used to evaluate the convergence validity of each construct. As shown in Table 4, the normalized factor loading for all constructs ranged from 0.77 to 0.94 ; all were greater than the recommended benchmark of 0.70 and were significant at $p<0.01$. The AVE values for all constructs ranged from 0.66 to 0.83 , which were above the recommended baseline of 0.5 [73]. The above results show that all measurement items have a high convergence validity.

\subsection{Discriminant Validity}

Discriminant validity refers to the degree to which two or more constructs are not related to each other [47]. According to Wang [14,26], the square roots of the AVE of each construct are all greater than the correlation between a pair of constructs, which thus supports the discriminant validity. As shown in Table 5, each construct had a good discriminant validity. 
Table 5. Results of descriptive statistics and correlations.

\begin{tabular}{|c|c|c|c|c|c|c|c|c|c|c|c|c|c|}
\hline \multirow{2}{*}{ Construct } & \multicolumn{13}{|c|}{ Convergence Validity } \\
\hline & Means & SD & ATT & EC & EPP & HAB_BEH & HAB_INT & INV_BEH & INV_INT & РBC & PMN & SN & SP \\
\hline AR & 4.079 & 0.743 & & & & & & & & & & & \\
\hline ATT & 4.503 & 0.64 & 0.888 & & & & & & & & & & \\
\hline $\mathrm{EC}$ & 4.191 & 0.692 & 0.429 & 0.862 & & & & & & & & & \\
\hline EPP & 3.51 & 0.917 & 0.189 & 0.455 & 0.849 & & & & & & & & \\
\hline HAB_BEH & 4.356 & 0.657 & 0.453 & 0.588 & 0.341 & 0.872 & & & & & & & \\
\hline HAB_INT & 4.451 & 0.622 & 0.465 & 0.593 & 0.301 & 0.829 & 0.896 & & & & & & \\
\hline INV_BEH & 4.161 & 0.694 & 0.379 & 0.585 & 0.474 & 0.617 & 0.619 & 0.862 & & & & & \\
\hline INV_INT & 4.104 & 0.669 & 0.385 & 0.651 & 0.463 & 0.627 & 0.634 & 0.732 & 0.844 & & & & \\
\hline PBC & 4.175 & 0.678 & 0.533 & 0.497 & 0.399 & 0.508 & 0.506 & 0.504 & 0.528 & 0.842 & & & \\
\hline PMN & 4.147 & 0.711 & 0.541 & 0.541 & 0.389 & 0.541 & 0.547 & 0.461 & 0.516 & 0.679 & 0.828 & & \\
\hline $\mathrm{SN}$ & 4.158 & 0.688 & 0.647 & 0.446 & 0.397 & 0.448 & 0.437 & 0.456 & 0.465 & 0.646 & 0.606 & 0.813 & \\
\hline SP & 3.38 & 0.984 & 0.124 & 0.369 & 0.762 & 0.252 & 0.2 & 0.387 & 0.402 & 0.345 & 0.279 & 0.353 & 0.908 \\
\hline
\end{tabular}

Note: Means are measured based on average factor scores; SD means standard deviation; values in the diagonal row (bold) are the square roots of AVEs and the others are the correlations between constructs. 


\subsection{Reliability Test}

Cronbach's alpha and the composite reliability values were used to evaluate the reliability of each construct [74]. As shown in Table 4, all the Cronbach's alpha values ranged from 0.74 to 0.89 , and the composite reliability values ranged from 0.85 to 0.93 . They were all higher than the recommended benchmark of 0.70 , and thereby provide support for the reliability of each construct [74].

\subsection{Hypothesis Test}

In the study, we used a structural model to explore the interrelationships between each research construct. The model was run by adopting a bootstrap resampling routine with 480 collected data and 5000 subsamples. The bootstrapping function was used to perform the testing of the hypotheses [73]. The standardized root mean square residual (SRMR) value was used to evaluate the goodness of fit of the model. An SRMR $<0.1$ indicates that the model fits well [38]. The SRMR value of the structural model in this study was 0.061 , which indicates that the overall fit of the research model is good. The $\mathrm{Q}^{2}$ value was used to evaluate the prediction correlation of the structural models. As shown in Table 6, the $\mathrm{Q}^{2}$ values of the six models included in this study were all greater than the minimum threshold of 0 , which indicates that the models all have high prediction correlation [30]. In addition, as shown in the $\mathrm{R}^{2}$ column of Table 6, the model explained $44.3 \%$ of the habituation intention, $49.8 \%$ of the investment intention, $69.9 \%$ of the habituation behavior, and $55.4 \%$ of the investment behavior. The overall explanatory ability of the model is good [72].

As shown in Table 6, the attitude (H1, $\beta=0.144, p<0.05)$, personal moral norm (H13, $\beta=0.199$, $p<0.01$ ), and environmental concern (H18a, $\beta=0.378, p<0.01$ ) had significant positive impacts on the habituation intention. Among them, the impact of environmental concern was the largest $\left(f^{2}=0.156\right)$, and the impact of the attitude was the smallest $\left(f^{2}=0.019\right)$. The impacts of subjective norm (H7, $\beta=-0.019, p=0.74)$, perceived behavior control (H9, $\beta=0.126, p=0.055)$, and knowledge of the electricity price policy (H5a, $\beta=-0.017, p=0.716$ ) were not significant.

The personal moral norm (H14, $\beta=0.084, p<0.05)$ and habituation intention $(\mathrm{H} 20, \beta=0.746$, $p<0.01$ ) had significant impacts on the habituation behavior, and the degree of influence of the habituation intention was much greater than the personal moral norm, with an effect size $\mathrm{f}^{2}$ of 23.107; while the impact of perceived behavioral control $(\mathrm{H} 10, \beta=0.073, p=0.071)$ was not significant.

The impacts of the attitude $(\mathrm{H} 2, \beta=0.006, p=0.897)$, subjective norm $(\mathrm{H} 8, \beta=0.055, p=0.328)$, and personal moral norm (H15, $\beta=0.95, p=0.104)$ on the investment intention were not significant. The perceived behavior control (H11, $\beta=0.157, p<0.01$ ), environmental concern (H19a, $\beta=0.444$, $p<0.01)$, and knowledge of the subsidy policy (H19a, $\beta=0.137, p<0.01)$ had significant positive impacts on the investment intention. The regression coefficient and effect size $\mathrm{f}^{2}$ indicated that the impact of environmental concern $\left(f^{2}=0.246\right)$ is much greater than the perceived behavior control $\left(\mathrm{f}^{2}=0.022\right)$ and knowledge of the subsidy policy $\left(\mathrm{f}^{2}=0.029\right)$.

The perceived behavior control (H12, $\beta=0.145, p<0.01)$ and investment intention $(\mathrm{H} 21, \beta=0.638$, $p<0.01)$ had significant positive impacts on the investment behavior. The effect size $\mathrm{f}^{2}$ of the investment intention was 15.382 , which is much higher than the perceived behavior control $\left(\mathrm{f}^{2}=2.917\right)$; while the impact of personal moral norm (H16, $\beta=0.034, p=0.511)$ was not significant.

Knowledge of the electricity price policy $(\mathrm{H} 3, \beta=0.225, p<0.01)$ had a significant positive impact on the attitude, while the impact of knowledge of the subsidy policy $(\mathrm{H} 4, \beta=-0.047, p=0.496)$ on the attitude was not significant. Environmental concern (H17, $\beta=0.541, p<0.01)$ had a significant positive impact on residents' personal moral norm. 
Table 6. Partial least squares (PLS) results of path coefficients and hypothesis testing.

\begin{tabular}{|c|c|c|c|c|c|c|c|c|c|}
\hline & Hypo & $\beta$ & CI-Min & CI-Max & $\mathrm{T}$ & \multirow{2}{*}{$\mathbf{R}^{2}$} & \multirow{2}{*}{$\mathbf{f}^{2}$} & \multirow{2}{*}{$\mathrm{Q}^{2}$} & \multirow{2}{*}{ Decision } \\
\hline \multicolumn{6}{|c|}{ Factors Affecting Habituation intention } & & & & \\
\hline H1 & ATT -> HAB_INT & $0.144^{* *}$ & 0.036 & 0.270 & 2.429 & \multirow{6}{*}{0.443} & 0.019 & \multirow{6}{*}{0.354} & Accept \\
\hline H7 & SN -> HAB_INT & -0.019 & -0.125 & 0.103 & 0.332 & & 0 & & Reject \\
\hline H9 & PBC -> HAB_INT & 0.126 & -0.004 & 0.253 & 1.918 & & 0.012 & & Reject \\
\hline H13 & PMN -> HAB_INT & $0.199 * * *$ & 0.065 & 0.328 & 2.931 & & 0.032 & & Accept \\
\hline $\mathrm{H} 5 \mathrm{a}$ & EPP -> HAB_INT & -0.017 & -0.110 & 0.077 & 0.364 & & 0 & & Reject \\
\hline H18a & EC -> HAB_INT & $0.378^{* * *}$ & 0.226 & 0.508 & 5.174 & & 0.156 & & Accept \\
\hline \multicolumn{10}{|c|}{ Factors Affecting Habituation behavior } \\
\hline $\mathrm{H} 10$ & PBC -> HAB_BEH & 0.073 & -0.006 & 0.155 & 1.808 & \multirow{3}{*}{0.699} & 0.009 & \multirow{3}{*}{0.528} & Reject \\
\hline H14 & PMN -> HAB_BEH & $0.084 * *$ & 0.012 & 0.164 & 2.203 & & 0.011 & & Accept \\
\hline $\mathrm{H} 20$ & HAB_INT ->HAB_BEH & $0.746^{* * *}$ & 0.678 & 0.805 & 23.107 & & 1.240 & & Accept \\
\hline \multicolumn{10}{|c|}{ Factors Affecting Investment intention } \\
\hline $\mathrm{H} 2$ & ATT -> INV_INT & 0.006 & -0.081 & 0.109 & 0.130 & \multirow{6}{*}{0.498} & 0 & \multirow{6}{*}{0.351} & Reject \\
\hline $\mathrm{H} 8$ & SN -> INV_INT & 0.055 & -0.055 & 0.162 & 0.979 & & 0.003 & & Reject \\
\hline H11 & PBC -> INV_INT & $0.157^{* * *}$ & 0.039 & 0.272 & 2.645 & & 0.022 & & Accept \\
\hline H15 & PMN -> INV_INT & 0.095 & -0.023 & 0.210 & 1.626 & & 0.008 & & Reject \\
\hline H6a & SP -> INV_INT & $0.137^{* * *}$ & 0.057 & 0.213 & 3.382 & & 0.029 & & Accept \\
\hline H19a & EC -> INV_INT & $0.444^{* * *}$ & 0.323 & 0.549 & 7.611 & & 0.246 & & Accept \\
\hline \multicolumn{10}{|c|}{ Factors Affecting Investment behavior } \\
\hline $\mathrm{H} 12$ & PBC -> INV_BEH & $0.145^{* * *}$ & 0.054 & 0.248 & 2.917 & \multirow{3}{*}{0.554} & 0.024 & \multirow{3}{*}{0.405} & Accept \\
\hline H16 & PMN -> INV_BEH & 0.034 & -0.073 & 0.131 & 0.657 & & 0.001 & & Reject \\
\hline $\mathrm{H} 21$ & INV_INT ->INV_BEH & $0.638^{* * *}$ & 0.553 & 0.712 & 15.382 & & 0.620 & & Accept \\
\hline \multicolumn{10}{|c|}{ Factors Affecting Attitude } \\
\hline H3 & EPP $->$ ATT & $0.225^{* * *}$ & 0.103 & 0.361 & 3.405 & \multirow[b]{2}{*}{0.032} & 0.022 & \multirow[b]{2}{*}{0.027} & Accept \\
\hline $\mathrm{H} 4$ & SP $->$ ATT & -0.047 & -0.185 & 0.091 & 0.68 & & 0.001 & & Reject \\
\hline \multicolumn{10}{|c|}{ Factors Affecting Personal moral norm } \\
\hline H17 & EC -> PMN & $0.541^{* * *}$ & 0.45 & 0.626 & 12.083 & 0.292 & 0.415 & 0.196 & Accept \\
\hline \multicolumn{4}{|c|}{ Mediating Effect } & $\beta$ & $\mathrm{CI}-\mathrm{Min}$ & CI-Max & \multicolumn{2}{|c|}{$T$} & Decision \\
\hline $\mathrm{H} 5 \mathrm{~b}$ & \multicolumn{3}{|c|}{ EPP -> ATT -> HAB_INT } & $0.043^{* *}$ & 0.006 & 0.075 & \multicolumn{2}{|c|}{2.22} & Mediation \\
\hline $\mathrm{H} 6 \mathrm{~b}$ & \multirow{2}{*}{\multicolumn{3}{|c|}{$\begin{array}{c}\text { SP }->\text { ATT }->\text { INV_INT } \\
\text { EC }->\text { PMN }->\text { HAB INT }\end{array}$}} & 0.001 & -0.020 & 0.029 & \multirow{2}{*}{\multicolumn{2}{|c|}{0.119}} & No Mediation \\
\hline $\mathrm{H} 18 \mathrm{~b}$ & & & & $0.108^{* * *}$ & 0.034 & 0.182 & & & Mediation \\
\hline $\mathrm{H} 19 \mathrm{~b}$ & \multicolumn{3}{|c|}{ EC $->$ PMN $->$ INV_INT } & 0.051 & -0.012 & 0.116 & \multicolumn{2}{|c|}{$\begin{array}{l}2.839 \\
1.597\end{array}$} & No Mediation \\
\hline
\end{tabular}


The results of the intermediary effect show that the attitude played a positive intermediary role between knowledge of the electricity price policy and residents' investment intention (H5b, $\beta=0.043$, $p<0.05)$, whereas its intermediary role between knowledge of the electricity price policy and residents' investment intention was not significant $(\mathrm{H} 6 \mathrm{~b}, \beta=-0.001, p=0.905)$. The personal moral norm played a positive intermediary role between environmental concern and residents' habituation intentions (H18b, $\beta=0.108, p<0.01$ ), whereas the intermediary role between environmental concern and investment intention was not significant $(\mathrm{H} 19 \mathrm{~b}, \beta=0.051, p=0.11)$.

\section{Discussion and Implications}

In this study, we constructed an extended TPB-NAM model to explore the different impacts of egoistic and altruistic psychological factors and policy factor on the two types of residential electricity-saving behaviors.

\subsection{Factors Affecting Habituation Electricity-Saving Behavior}

Residents' knowledge of the electricity price policy indirectly affects their habituation intentions by affecting their attitude. The direct impact of residents' knowledge of the electricity price policy on their habituation intentions is not significant, but it has a significant positive impact on residents' attitude; also, their attitude has a significant positive impact on their habituation intentions. It is shown that residents' knowledge of the electricity price policy indirectly affects their habituation intention by affecting their attitude. The more residents know about the current electricity price policy, the more positive their attitude towards electricity saving will be and the stronger their habituation intentions will be. The relatively low price elasticity of the residential electricity demand, combined with the residential electricity demand drivers of the development of urbanization and the growth of household incomes, suggest that the current electricity price policy has a relatively limited direct impact on Chinese residential electricity consumption [75]. However, residents' knowledge of the electricity price policy can indirectly promote their habituation intentions by improving their attitude.

Environmental concern can directly affect residents' habituation intentions, and it can also indirectly affect their habituation intentions through the personal moral norm. Environmental concern has a significant positive impact, which is consistent with previous research results [56]. The results of the intermediary effect show that environmental concern can also indirectly affect residents' habituation intentions by affecting their personal moral norms. The improvement of residents' environmental concern will enhance their moral responsibility for energy-saving and emission-reduction issues, thereby promoting their habituation intentions.

Personal moral norm has a significant positive impact on residents' habituation intentions and behaviors, whereas perceived behavioral control has no significant effect on both. This result is similar to relevant researches such as Wang et al. [15]. Habituation behaviors, such as turning off lights when leaving, are easy for most people to perform, and these behaviors are hardly affected by the behavior control ability perceived by residents [15]. Residents who have a sense of moral responsibility will have a stronger saving intention, and they are more likely to adopt corresponding behaviors [15].

\subsection{Factors Affecting Investment Electricity-Saving Behavior}

Residents' knowledge of the subsidy policy directly affects their investment intentions. The more residents know about the subsidy policy in respect of efficient appliances, the stronger their intention will be to purchase these appliances and other relevant technologies. This conclusion is consistent with previous research results [43]. In contrast to the electricity price policy, residents' knowledge of the subsidy policy does not indirectly affect their investment intentions through their attitude. On the one hand, compared to the electricity price policy, the subsidy policy can bring more direct economic benefits to the residents, and this can thereby have a direct positive impact on their investment intentions. On the other hand, residents' attitudes only have a significant impact on their habituation intentions, but the impact on their investment ones is not significant. There may be two reasons 
for this difference. First, the high cost of investment behavior restrains the impact of the attitude on their investment intentions. Residents' energy-saving behaviors are largely dominated by their economic motivations. Residents will weigh the saving behaviors and their costs [17,76]. Investment behavior requires direct costs; that is, the purchase of efficient equipment. Therefore, the impact of residents' attitudes on investment behavior is relatively limited [77]. Second, some residents do not have a comprehensive understanding of electricity-saving behaviors and fail to recognize the effects of investment behaviors such as purchasing efficient appliances. Ajzen and Fishbein [78] pointed out that strong attitude-behavior relationships can only be obtained under high correspondence between at least the target and action elements of the attitudinal and behavioral entities. Residents who do not have a comprehensive understanding of electricity-saving behavior tend to equate this behavior with the habituation behavior, which can save electricity directly, rather than the investment behavior of indirect electricity conservation. Therefore, the impact of attitudes on investment intentions is not significant.

Environmental concern directly affects residents' investment intentions. Because the impact of the personal moral norm on investment intention is not significant, so there is no intermediary role of the personal moral norm in the relationship between environmental concern and investment intentions. Environmental concern will have a significant directly positive impact. Residents with higher environmental concern are more inclined to purchase efficient appliances, which is consistent with previous research results [42].

Perceived behavior control has a significant positive impact on residents' investment intentions and behaviors, while the personal moral norm has no significant impact on both. Compared with habituation behaviors, such as turning off lights when leaving, investment behaviors, such as purchasing and using efficient appliances, are more affected by the knowledge and resources owned by individuals [2]. Therefore, perceived behavioral control has a significant impact on investment intentions and behaviors, and this result is consistent with previous research on pro-environment intentions and behaviors [39,79]. The insignificant impact of the personal moral norm on the ones is different from the studies about other pro-environment behaviors [33]. Our analysis shows that this difference is also due to the high cost of investment behaviors. The high cost of investment behavior restrains the impact of the personal moral norm on the investment intention; that is, driven by economic factors, even if residents have high personal moral norms, they may not be inclined to purchase expensive efficient appliances.

The impact of the subjective norm on both types of electricity-saving intention is not significant. That is, pressure from friends and other members of society will not affect the two types of intentions. This result is consistent with the research results of Al Mamun et al. [80] and Li et al. [2]. Electricity-saving behaviors are private behaviors that occur within the home and are not easily observed by the outside world. Therefore, compared to other pro-environment behaviors, such as the behaviors in the workplace [27], the impact of external social pressures on household electricity-saving behaviors is relatively limited.

Based on the above conclusions, some implications can be given for the production and marketing of efficient appliances, the implementation of policies by governments and pro-environment organizations, and the development of user strategies by electric power companies that effectively promote household energy-saving and emission reductions. The main policy implications are shown in Figure 4.

First, household electricity saving can be promoted through technological innovation to reduce the cost of efficient appliances and strengthen consumers' knowledge of these appliances by improving the design of energy efficiency labels for household appliances. The reduction of the production cost of efficient appliances has reduced the economic cost of electricity conservation from the source and has thus promoted the residents' intention to save electricity $[17,76]$. The energy efficiency label is used to reduce the information cost of consumers and help consumers to quickly and easily understand the energy efficiency level of appliances. As a means of intervention, the energy efficiency label has a significant positive impact on consumers' intention to purchase efficient appliances [19]. At present, the information on the energy efficiency labels of household appliances is too professional, which makes 
it difficult for consumers to understand, so it is easy to ignore key information. The design of energy efficiency labels can be improved, and energy consumption information and energy saving costs can be displayed more simply and intuitively. This would improve residents' intention of acquiring these appliances.

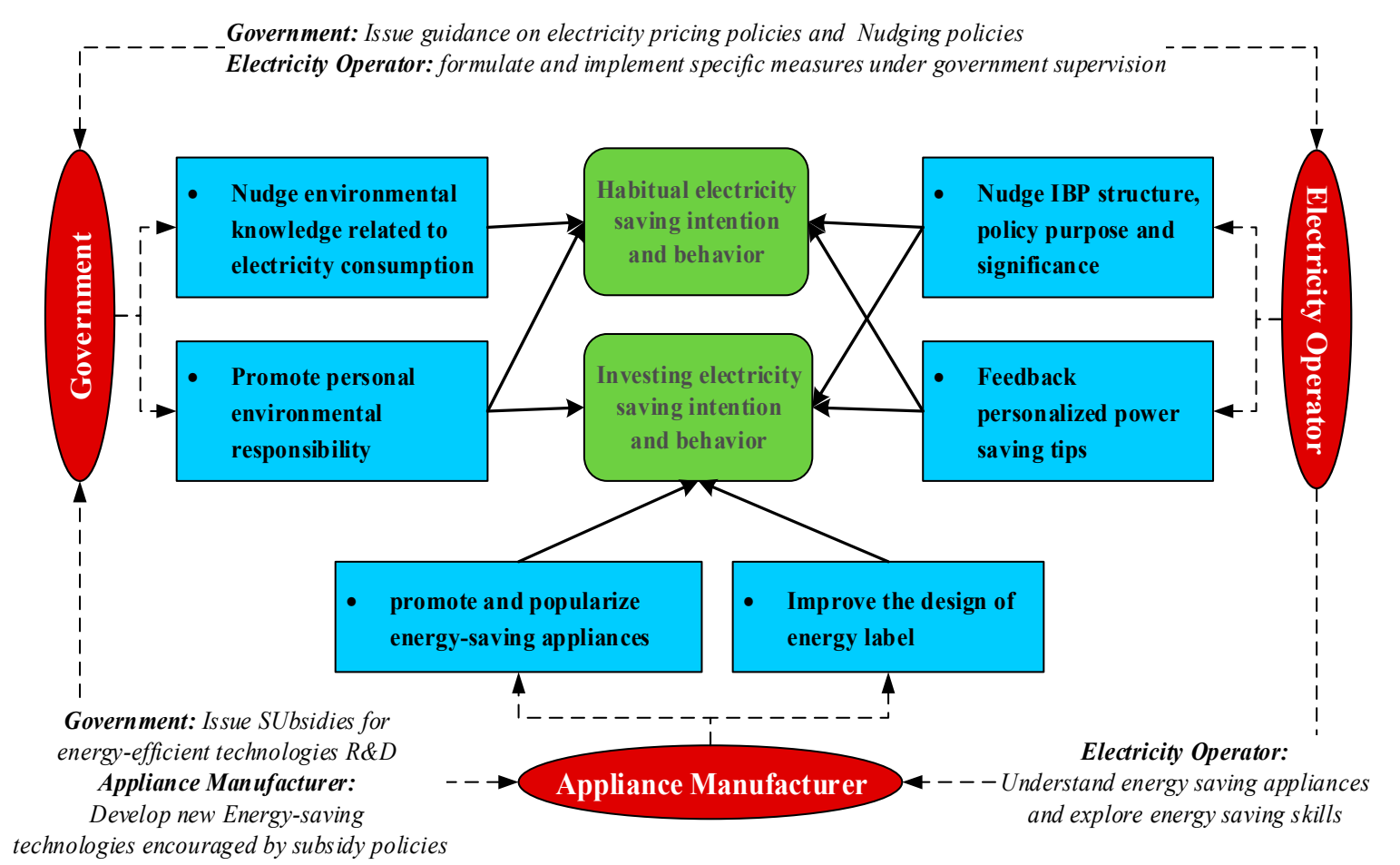

Figure 4. Policy implications.

Second, a personalized information push scheme should be developed to provide home energy feedback to residents to promote their knowledge of the block tariffs policy. This also would improve residents' environmental concern. The effect of this household energy consumption feedback has been verified by many scholars $[81,82]$. At present, electricity bills are the most important carrier for household energy consumption feedback. Although smart meters have become popular, they are not designed from the perspective of users. Therefore, household electricity bills should be improved to be able to feed useful detailed information back to households in respect of their electricity consumption structure under the block tariffs policy, and thereby promote users' knowledge of the block tariffs policy. In addition, electric power companies can make full use of big data analysis technology to tap the characteristics of users' electricity consumption patterns, consumption preferences, electricity consumption behaviors, and pro-environment behaviors, which will enable them to develop personalized information push schemes to promote energy-saving technologies and promote users' environmental concern.

\section{Conclusions and Limitations}

Based on the survey data of 480 households' electricity consumption behaviors in Hefei, this study constructs an extended TPB-NAM model to explore the difference between the influence factors of habitual and investment energy-saving behavior. We mainly focus on the direct and indirect impact of altruistic psychological factor (environmental concern) and external policy factor (residents' knowledge of the electricity price policy and subsidy policy) on habitual and investment behavior. The main conclusions are as follows.

(1) The impacts of external policy factors on the two types of willingness to save electricity. Residents' knowledge of the electricity price policy indirectly affects their habituation intentions 
by affecting their attitude, but the direct effect is not significant. On the contrary, residents' knowledge of the subsidy policy directly affects their investment intentions, but the indirect effect is not significant.

(2) The impacts of altruistic policy factors on the two types of willingness and behaviors to save electricity. Environmental concern can directly affect residents' habituation saving intentions and can also indirectly affect residents' habituation ones through their personal moral norm, whereas it has only a direct positive impact on their investment intentions, and the indirect effect is not significant. The personal moral norm has a significant positive impact on residents' habituation intentions and behaviors, whereas its impact on residents' investment ones and behaviors are not significant.

(3) The impacts of egoistic policy factors on the two types of willingness and behaviors to save electricity. Residents' attitude towards electricity saving has a significant positive impact on their habituation saving intentions, but the impact on their investment ones is not significant. Perceived behavior control has a significant positive impact on residents' investment saving intentions and behaviors, whereas its impact on residents' habituation ones and behaviors are not significant. The impact of the subjective norm on both types is not significant.

Although some valuable conclusions have been offered, this study still has two limitations. First, only the urban residents in Hefei are included in the survey, which may limit the applicability of the research results. Hefei can be a representative of the central-eastern cities in China to illustrate the residents' electricity-saving behavior, and the findings of this study may only be suitable for the central-eastern cities in China. Weather differs widely among north and south parts of China, as does the heating demand and means in winter, which leads to large differences of households' energy structure and consumption features. According to the "Plan for Clean Winter Heating in Northern China (2017-2021)" released by the NEA, by the end of 2016, coal heating accounted for $83 \%$ of the total heating area in northern China, while natural gas accounted for $11 \%$, and electricity only $2 \%$. In contrast, most families in southern China choose air conditioning and electric heating equipment for heating in winter, and electricity is the main heating energy in southern China. Therefore, the future research should be aimed at northern cities and a wider range of residential users so that the research conclusions are more general; also, the differences in the investment and habituation behaviors by residents in different areas or by urban and rural residents can also be studied. Second, all the variables in this study are based on the self-reporting of the respondents, so the survey results may have a degree of social expectation bias [83].

Author Contributions: Conceptualization, project administration, L.L.; data curation, formal analysis, software, H.M.; funding acquisition, methodology, writing - review and editing, L.L. and R.Y.; resources, R.Y.; supervision, validation, visualization, X.L.; writing - original draft, L.L. and H.M. All authors have read and agreed to the published version of the manuscript.

Funding: This research was funded by the National Natural Science Foundation of China, No. 71503065, 71704045; Humanities and Social Science Fund of Ministry of Education of China, No.14YJC630061.

Conflicts of Interest: The authors declare no conflict of interest.

\section{References}

1. Zhang, C.-Y.; Yu, B.; Wang, J.-W.; Wei, Y.-M. Impact factors of household energy-saving behavior: An empirical study of Shandong Province in China. J. Clean. Prod. 2018, 185, 285-298. [CrossRef]

2. Li, G.; Li, W.; Jin, Z.; Wang, Z. Influence of Environmental Concern and Knowledge on Households' Willingness to Purchase Energy-Efficient Appliances: A Case Study in Shanxi, China. Sustainability 2019, 11, 1073. [CrossRef]

3. Cui, P.; Xia, S.; Hao, L. Do different sizes of urban population matter differently to $\mathrm{CO}_{2}$ emission in different regions? Evidence from electricity consumption behavior of urban residents in China. J. Clean. Prod. 2019, 240, 118207. [CrossRef] 
4. National Bureau of Statistics. China Statistical Yearbook 2019. Available online: http://www.stats.gov.cn/tjsj/ ndsj/2019/indexch.htm (accessed on 30 March 2020).

5. Cao, J.; Ho, M.S.; Li, Y.; Newell, R.G.; Pizer, W.A. Chinese residential electricity consumption: Estimation and forecast using micro-data. Resour. Energy Econ. 2019, 56, 6-27. [CrossRef]

6. Biresselioglu, M.E.; Demir, M.H.; Rashid, A.; Solak, B.; Ozyorulmaz, E. What are the preferences of household energy use in Pakistan? Findings from a national survey. Energy Build. 2019, 205, 109538. [CrossRef]

7. Gallo Cassarino, T.; Sharp, E.; Barrett, M. The impact of social and weather drivers on the historical electricity demand in Europe. Appl. Energy 2018, 229, 176-185. [CrossRef]

8. Khan, I.; Jack, M.W.; Stephenson, J. Identifying residential daily electricity-use profiles through time-segmented regression analysis. Energy Build. 2019, 194, 232-246. [CrossRef]

9. Roberts, M.B.; Haghdadi, N.; Bruce, A.; MacGill, I. Characterisation of Australian apartment electricity demand and its implications for low-carbon cities. Energy 2019, 180, 242-257. [CrossRef]

10. Taale, F.; Kyeremeh, C. Drivers of households' electricity expenditure in Ghana. Energy Build. 2019, $205,109546$. [CrossRef]

11. Kavousian, A.; Rajagopal, R.; Fischer, M. Determinants of residential electricity consumption: Using smart meter data to examine the effect of climate, building characteristics, appliance stock, and occupants' behavior. Energy 2013, 55, 184-194. [CrossRef]

12. Vassileva, I.; Dahlquist, E.; Wallin, F.; Campillo, J. Energy consumption feedback devices' impact evaluation on domestic energy use. Appl. Energy 2013, 106, 314-320. [CrossRef]

13. Barr, S.; Gilg, A.W.; Ford, N. The household energy gap: Examining the divide between Habituation-And purchase-related conservation behaviours. Energy Policy 2005, 33, 1425-1444. [CrossRef]

14. Jansson, J.; Marell, A.; Nordlund, A. Elucidating Green Consumers: A Cluster Analytic Approach on Proenvironmental Purchase and Curtailment Behaviors. J. Euromark. 2009, 18, 245-267. [CrossRef]

15. Wang, B.; Wang, X.; Guo, D.; Zhang, B.; Wang, Z. Analysis of factors influencing residents' habituation energy-saving behaviour based on NAM and TPB models: Egoism or altruism? Energy Policy 2018, 116, 68-77. [CrossRef]

16. Dixon, T.; Eames, M. Scaling up: The challenges of urban retrofit. Build. Res. Inform. 2013, 41, 499-503. [CrossRef]

17. Trotta, G. Factors affecting energy-saving behaviours and energy efficiency investments in British households. Energy Policy 2018, 114, 529-539. [CrossRef]

18. Jia, J.-J.; Xu, J.-H.; Fan, Y.; Ji, Q. Willingness to accept energy-saving measures and adoption barriers in the residential sector: An empirical analysis in Beijing, China. Renew. Sustain. Energy Rev. 2018, 95, 56-73. [CrossRef]

19. Wang, Z.; Sun, Q.; Wang, B.; Zhang, B. Purchasing intentions of Chinese consumers on energy-efficient appliances: Is the energy efficiency label effective? J. Clean. Prod. 2019, 238, 117896. [CrossRef]

20. Umit, R.; Poortinga, W.; Jokinen, P.; Pohjolainen, P. The role of income in energy efficiency and curtailment behaviours: Findings from 22 European countries. Energy Res. Soc. Sci. 2019, 53, 206-214. [CrossRef]

21. Soltani, M.; Rahmani, O.; Beiranvand Pour, A.; Ghaderpour, Y.; Ngah, I.; Misnan, S.H. Determinants of Variation in Household Energy Choice and Consumption: Case from Mahabad City, Iran. Sustainability 2019, 11, 4775. [CrossRef]

22. Zhao, X.; Cheng, H.; Zhao, H.; Jiang, L.; Xue, B. Survey on the households' energy-saving behaviors and influencing factors in the rural loess hilly region of China. J. Clean. Prod. 2019, 230, 547-556. [CrossRef]

23. Hong, J.; She, Y.; Wang, S.; Dora, M. Impact of psychological factors on energy-saving behavior: Moderating role of government subsidy policy. J. Clean. Prod. 2019, 232, 154-162. [CrossRef]

24. Thøgersen, J.; Grønhøj, A. Electricity saving in households-A social cognitive approach. Energy Policy 2010, 38, 7732-7743. [CrossRef]

25. Song, Y.; Zhao, C.; Zhang, M. Does haze pollution promote the consumption of energy-saving appliances in China? An empirical study based on norm activation model. Resour. Conserv. Recycl. 2019, 145, 220-229. [CrossRef]

26. Wang, S.; Lin, S.; Li, J. Exploring the effects of non-cognitive and emotional factors on household electricity saving behavior. Energy Policy 2018, 115, 171-180. [CrossRef] 
27. Wang, S.; Wang, J.; Ru, X.; Li, J.; Zhao, D. Understanding employee's electricity conservation behavior in workplace: Do normative, emotional and habituation factors matter? J. Clean. Prod. 2019, 215, 1070-1077. [CrossRef]

28. Bagheri, A.; Bondori, A.; Allahyari, M.S.; Damalas, C.A. Modeling farmers' intention to use pesticides: An expanded version of the theory of planned behavior. J. Environ. Manag. 2019, 248, 109291. [CrossRef]

29. Si, H.; Shi, J.-G.; Tang, D.; Wu, G.; Lan, J. Understanding intention and behavior toward sustainable usage of bike sharing by extending the theory of planned behavior. Resour. Conserv. Recycl. 2020, 152, 104513. [CrossRef]

30. Lopes, J.R.N.; Kalid, R.d.A.; Rodríguez, J.L.M.; Ávila Filho, S. A new model for assessing industrial worker behavior regarding energy saving considering the theory of planned behavior, norm activation model and human reliability. Resour. Conserv. Recycl. 2019, 145, 268-278. [CrossRef]

31. Icek, A. From Intentions to Actions: A Theory of Planned Behavior; Springer: Berlin/Heidelberg, Germany, 1985.

32. Schwartz, S.H. Normative Influences on Altruism. In Advances in Experimental Social Psychology; Academic Press: Cambridge, MA, USA, 1977; Volume 10, pp. 221-279.

33. Ansu-Mensah, P.; Bein, M.A. Towards sustainable consumption: Predicting the impact of social-psychological factors on energy conservation intentions in Northern Cyprus. Nat. Resour. Forum 2019, 43, 181-193. [CrossRef]

34. Ali, S.; Ullah, H.; Akbar, M.; Akhtar, W.; Zahid, H. Determinants of Consumer Intentions to Purchase Energy-Saving Household Products in Pakistan. Sustainability 2019, 11, 1462. [CrossRef]

35. He, X.; Zhan, W. How to activate moral norm to adopt electric vehicles in China? An empirical study based on extended norm activation theory. J. Clean. Prod. 2018, 172, 3546-3556. [CrossRef]

36. Yang, R.; Wei, J.; Lu, L.; Li, L. Air pollution and green consumption of consumers in China's urban areas: A norm activation perspective. Hum. Ecol. Risk Assess. Int. J. 2019, 1-23. [CrossRef]

37. Kaffashi, S.; Shamsudin, M.N. Transforming to a low carbon society; an extended theory of planned behaviour of Malaysian citizens. J. Clean. Prod. 2019, 235, 1255-1264. [CrossRef]

38. Sujata, M.; Khor, K.-S.; Ramayah, T.; Teoh, A.P. The role of social media on recycling behaviour. Sustain. Prod. Consum. 2019, 20, 365-374. [CrossRef]

39. Yadav, R.; Pathak, G.S. Young consumers' intention towards buying green products in a developing nation: Extending the theory of planned behavior. J. Clean. Prod. 2016, 135, 732-739. [CrossRef]

40. Shi, H.; Wang, S.; Guo, S. Predicting the impacts of psychological factors and policy factors on individual's PM2.5 reduction behavior: An empirical study in China. J. Clean. Prod. 2019, 241, 118416. [CrossRef]

41. Higueras-Castillo, E.; Liébana-Cabanillas, F.J.; Muñoz-Leiva, F.; García-Maroto, I. Evaluating consumer attitudes toward electromobility and the moderating effect of perceived consumer effectiveness. J. Retail. Consum. Serv. 2019, 51, 387-398. [CrossRef]

42. Ru, X.; Wang, S.; Chen, Q.; Yan, S. Exploring the interaction effects of norms and attitudes on green travel intention: An empirical study in eastern China. J. Clean. Prod. 2018, 197, 1317-1327. [CrossRef]

43. Wang, S.; Li, J.; Zhao, D. The impact of policy measures on consumer intention to adopt electric vehicles: Evidence from China. Transp. Res. Part A Policy Pract. 2017, 105, 14-26. [CrossRef]

44. Yang, S.; Cheng, P.; Li, J.; Wang, S. Which group should policies target? Effects of incentive policies and product cognitions for electric vehicle adoption among Chinese consumers. Energy Policy 2019, 135, 111009. [CrossRef]

45. Pan, J.Y.; Truong, D. Passengers' intentions to use low-cost carriers: An extended theory of planned behavior model. J. Air Transp. Manag. 2018, 69, 38-48. [CrossRef]

46. Cheung, L.T.O.; Chow, A.S.Y.; Fok, L.; Yu, K.-M.; Chou, K.-L. The effect of self-determined motivation on household energy consumption behaviour in a metropolitan area in southern China. Energy Effic. 2016, 10, 549-561. [CrossRef]

47. Ru, X.; Wang, S.; Yan, S. Exploring the effects of normative factors and perceived behavioral control on individual's energy-saving intention: An empirical study in eastern China. Resour. Conserv. Recycl. 2018, 134, 91-99. [CrossRef]

48. Ru, X.; Qin, H.; Wang, S. Young people's behaviour intentions towards reducing PM2.5 in China: Extending the theory of planned behaviour. Resour. Conserv. Recycl. 2019, 141, 99-108. [CrossRef] 
49. Nie, H.; Vasseur, V.; Fan, Y.; Xu, J. Exploring reasons behind careful-use, energy-saving behaviours in residential sector based on the theory of planned behaviour: Evidence from Changchun, China. J. Clean. Prod. 2019, 230, 29-37. [CrossRef]

50. Gkargkavouzi, A.; Halkos, G.; Matsiori, S. Environmental behavior in a private-sphere context: Integrating theories of planned behavior and value belief norm, self-identity and habit. Resour. Conserv. Recycl. 2019, 148, 145-156. [CrossRef]

51. Wan, C.; Shen, G.Q.; Choi, S. Experiential and instrumental attitudes: Interaction effect of attitude and subjective norm on recycling intention. J. Environ. Psychol. 2017, 50, 69-79. [CrossRef]

52. Shi, H.; Fan, J.; Zhao, D. Predicting household PM2.5-reduction behavior in Chinese urban areas: An integrative model of Theory of Planned Behavior and Norm Activation Theory. J. Clean. Prod. 2017, 145, 64-73. [CrossRef]

53. Maleksaeidi, H.; Keshavarz, M. What influences farmers' intentions to conserve on-farm biodiversity? An application of the theory of planned behavior in fars province, Iran. Glob. Ecology Conserv. 2019, 20 , e00698. [CrossRef]

54. Lanzini, P.; Khan, S.A. Shedding light on the psychological and behavioral determinants of travel mode choice: A meta-analysis. Transp. Res. Part F Traffic Psychol. Behav. 2017, 48, 13-27. [CrossRef]

55. Zhang, X.; Liu, J.; Zhao, K. Antecedents of citizens' environmental complaint intention in China: An empirical study based on norm activation model. Resour. Conserv. Recycl. 2018, 134, 121-128. [CrossRef]

56. Mishal, A.; Dubey, R.; Gupta, O.K.; Luo, Z. Dynamics of environmental consciousness and green purchase behaviour: An empirical study. Int. J. Clim. Change Strateg. Manag. 2017, 9, 682-706. [CrossRef]

57. Kautish, P.; Sharma, R. Study on relationships among terminal and instrumental values, environmental consciousness and behavioral intentions for green products. J. Indian Bus. Res. 2018. [CrossRef]

58. Chen, M.-F.; Tung, P.-J. Developing an extended Theory of Planned Behavior model to predict consumers' intention to visit green hotels. Int. J. Hosp. Manag. 2014, 36, 221-230. [CrossRef]

59. Shi, H.; Wang, S.; Zhao, D. Exploring urban resident's vehicular PM2.5 reduction behavior intention: An application of the extended theory of planned behavior. J. Clean. Prod. 2017, 147, 603-613. [CrossRef]

60. Liu, Y.; Liu, R.; Jiang, X. What drives low-carbon consumption behavior of Chinese college students? The regulation of situational factors. Nat. Hazards 2018, 95, 173-191. [CrossRef]

61. Sarkis, A.M. A comparative study of theoretical behaviour change models predicting empirical evidence for residential energy conservation behaviours. J. Clean. Prod. 2017, 141, 526-537. [CrossRef]

62. Ding, Z.; Wang, G.; Liu, Z.; Long, R. Research on differences in the factors influencing the energy-saving behavior of urban and rural residents in China-A case study of Jiangsu Province. Energy Policy 2017, 100, 252-259. [CrossRef]

63. Li, L.; Liu, Y.; Fan, J.-L.; Shen, B. Does the knowledge and acceptance of an increasing block tariffs policy strengthen residents' gas-saving intention? Evidence from household-level survey data. J. Clean. Prod. 2019, 223, 289-300. [CrossRef]

64. Wang, Z.; Wang, X.; Guo, D. Policy implications of the purchasing intentions towards energy-efficient appliances among China's urban residents: Do subsidies work? Energy Policy 2017, 102, 430-439. [CrossRef]

65. Pothitou, M.; Hanna, R.F.; Chalvatzis, K.J. Environmental knowledge, pro-environmental behaviour and energy savings in households: An empirical study. Appl. Energy 2016, 184, 1217-1229. [CrossRef]

66. Urban, J.; Ščasný, M. Exploring domestic energy-saving: The role of environmental concern and background variables. Energy Policy 2012, 47, 69-80. [CrossRef]

67. National Energy Administration. The National Energy Administration Released Statistics on the Country's Power Industry in 2018. Available online: http://www.nea.gov.cn/2019-01/18/c_137754977.htm (accessed on 30 March 2020).

68. Hefei Municipal Bureau of Statistics. Hefei Statistical Yearbook 2019. Available online: http://tj.hefei.gov.cn/ tjnj/index.html (accessed on 30 March 2020).

69. Anderson, J.C.; Gerbing, D.W. Structural equation modeling in practice: A review and recommended two-step approach. Psychol. Bull. 1988, 103, 411-423. [CrossRef]

70. Iacobucci, D. Everything you always wanted to know about SEM (structural equations modeling) but were afraid to ask. J. Consum. Psychol. 2009, 19, 673-680. [CrossRef]

71. Reinartz, W.; Haenlein, M.; Henseler, J. An empirical comparison of the efficacy of covariance-based and variance-based SEM. Int. J. Res. Mark. 2009, 26, 332-344. [CrossRef] 
72. Hair, J.F.; Ringle, C.M.; Sarstedt, M. PLS-SEM: Indeed a Silver Bullet. J. Mark. Theory Pract. 2014, 19, $139-152$. [CrossRef]

73. Hair, J.F.; Ringle, C.M.; Sarstedt, M. Partial Least Squares: The Better Approach to Structural Equation Modeling? Long Range Plan. 2012, 45, 312-319. [CrossRef]

74. Fornell, C.; Larcker, D.F. Evaluating Structural Equation Models with Unobservable Variables and Measurement Error. J. Mark. Res. 1981, 18, 382-388. [CrossRef]

75. Khanna, N.Z.; Guo, J.; Zheng, X. Effects of demand side management on Chinese household electricity consumption: Empirical findings from Chinese household survey. Energy Policy 2016, 95, 113-125. [CrossRef]

76. Caird, S.; Roy, R.; Herring, H. Improving the energy performance of UK households: Results from surveys of consumer adoption and use of low- and zero-carbon technologies. Energy Effic. 2008, 1, 149-166. [CrossRef]

77. Ramos, A.; Labandeira, X.; Löschel, A. Pro-environmental Households and Energy Efficiency in Spain. Environ. Resour. Econ. 2015, 63, 367-393. [CrossRef]

78. Ajzen, I.; Fishbein, M. Attitude-behavior relations: A theoretical analysis and review of empirical research. Psychol. Bull. 1977, 84, 888-918. [CrossRef]

79. Paul, J.; Modi, A.; Patel, J. Predicting green product consumption using theory of planned behavior and reasoned action. J. Retail. Consum. Serv. 2016, 29, 123-134. [CrossRef]

80. Al Mamun, A.; Mohiuddin, M.; Ahmad, G.; Thurasamy, R.; Fazal, S. Recycling Intention and Behavior among Low-Income Households. Sustainability 2018, 10, 2407. [CrossRef]

81. Sudarshan, A. Nudges in the marketplace: The response of household electricity consumption to information and monetary incentives. J. Econ. Behav. Organ. 2017, 134, 320-335. [CrossRef]

82. Cattaneo, C. Internal and external barriers to energy efficiency: Which role for policy interventions? Energy Effic. 2019, 12, 1293-1311. [CrossRef]

83. Wan, C.; Shen, G.Q.; Yu, A. The role of perceived effectiveness of policy measures in predicting recycling behaviour in Hong Kong. Resour. Conserv. Recycl. 2014, 83, 141-151. [CrossRef]

(C) 2020 by the authors. Licensee MDPI, Basel, Switzerland. This article is an open access article distributed under the terms and conditions of the Creative Commons Attribution (CC BY) license (http://creativecommons.org/licenses/by/4.0/). 